\title{
THE ESTABLISHMENT OF CORDIAL RELATIONS BETWEEN THE BAR AND THE CORPORATE FIDUCIARIES
}

\author{
JoHN G. JACKSON*
}

As the title to this article indicates, relations between the legal profession and corporate fiduciaries have not always been cordial. Sufficient evidence of this can be found in the history of litigation between the two. ${ }^{1}$ In all of these cases the courts have passed upon the question of whether or not a corporate fiduciary can prepare wills, trust agreements, escrows and like documents for its customers, and the almost unanimous holding of the courts is that such services constitute the practice of the law by or on behalf of a corporation and are unlawful.

These practices grew out of the efforts of banks and trust companies to increase their fiduciary business. Personal trust departments forty or fifty years ago were small affairs compared to their present size. Business was very definitely increased by the solicitation of the bank's customers, who were persuaded to draw wills naming the bank as executor and to create trusts of which the bank was trustee. Competition between the banks and trust companies themselves increased the efforts to secure this type of business, and offering preparation of wills and trust agreements without charge was not an unnatural development. Thus this practice spread, and no organized effort to end these methods of securing business was made prior to I9I3, when the New York County Lawyers Association created a committee on the unlawful practice of the law.

In I9I7 the Appellate Division of the New York Supreme Court handed down the first decision by an appellate court holding a trust company guilty of the crime of practicing law in violation of a statute limiting the right to practice law to duly qualified and duly admitted individuals. ${ }^{2}$ In that case the defendant trust com-

*A.B., I901, LL.B., I903, Columbia University. Member of the New York Bar. Member of firm of lackson, Fuller, Nash \& Brophy, New York City. Chairman of the Committee on Unauthorized Practice of the Law of the American Bar Association, I931-1934. Contributor of numerous articles to legal periodicals on the subject of unauthorized practice of law.

I The cases are collected in Brand, Unautronized Practice Decisions (1937) 780. To this list should be added Judd v. City Trust \& Savings Bank, I33 Ohio St. 81 (1937); Detroit Bar Ass'n v. Union Guardian Trust Co., 276 N. W. 365 (Mich. I937); Detroit Bar Ass'n v. Detroit Trust Co., 276 N. W. 372 (Mich. 1937); Detroit Bar Ass'n v. Equitable Trust Co., 276 N. W. 372 (Mich. 1937).

${ }^{2}$ People v. People's Trust Co., 180 App. Div. 494,167 N. Y. Supp. 767 (1917). 
pany had advertised that it would furnish without obligation advice as to the making of wills. A prospective customer came to the defendant with a copy of the advertisement. A trust officer called up an attorney connected with the defendant's regularly retained firm of lawyers, who came to the office, took the customer's instructions, drafted the will and on the following day supervised its execution. The defendant trust company was named as executor and no charge was made for the lawyer's services. Subsequent decisions on similar litigated controversies have supported the view of the New York court.

As the opposition of the bar to these practices increased the controversy became more severe. Lawyers who opposed the practice of corporations furnishing legal services were charged with being moved by selfish motives alone and that the end really sought was to retain to themselves appointment as executors and trustees. It was claimed that only lawyers specially experienced in trust company work were competent to draw wills and trusts. The lawyers retorted that the fiduciaries were commercializing the practice of the law for their own benefit and that advice given by the fiduciaries' lawyers to prospective trustors and testators was not the disinterested advice which a lawyer owed to his client. And so the matter went along until about ten years ago, when efforts to end the controversy were really undertaken by both the lawyers and the fiduciaries.

At the outset it was difficult to bring about a settlement of local controversies and a good deal of litigation resulted. However, both the Committee on Relations with the Bar of the Trust Division of the American Bankers' Association and the American Bar Association Committee on the Unauthorized Practice of the Law continued their earnest efforts toward bringing about a proper respect for and recognition of the rights both of the bar and of the fiduciaries. Local associations of fiduciaries and lawyers, "made wiser by the steady growth of truth," finally sat down together to find a way to end a controversy which profited neither. This attitude was well illustrated in 1931, when the American Bar Association held its annual meeting at Atlantic City. In connection with that event the Committee on Unauthorized Practice held an open meeting to discuss the relations between corporate fiduciaries and the bar, which was addressed by Mr. Merrel P. Callaway, head of the Trust Department of the Guaranty Trust Company of New York. He stated in substance that it was his belief that the banks and trust companies of New York did not practice law or desire to practice law; that they did not furnish attorneys to draw wills or trust agreements, nor have it done at their expense by any other attorneys; that it was not only their practice but their desire to have wills and trust agreements drawn by the testator's or trustor's own attorney; and that the responsibilities of administering such estates under modern conditions were great enough without assuming the responsibility for the drawing of the instrument, regardless of any legal right to do so. Nothing could have been more helpful toward a better relationship than Mr. Callaway's statement at that time. 
Both the committee of the Trust Division and that of the American Bar Association urged a spirit of conciliation and fair play and that every reasonable effort be made to dispose of controversial questions by negotiation and agreement, rather than by litigation. The result has been that bar associations and fiduciary associations have agreed in over 33 instances on a joint declaration of acceptable principles. ${ }^{3}$ In other instances consent court decrees establishing principles agreeable to both parties have terminated law suits that otherwise would have gone through the usual course of delay and expense and resulted in increased antagonism. While it would be interesting, it would require far too much space to analyze the different types of declarations and the different subjects covered by them. Many of them reflect local conditions, but it is generally true that in all of them are found the principles approved and adopted in 1933 by the American Bankers' Association and later made a part of the Code of Fair Competition for Bankers. Among the more important of these principles are the following:

"With respect to the acceptance of personal trust business the two determining factors are these: Is trust service needed, and can the service be rendered properly?" (Article II, Sec. I)

"It is the duty of a trustee to administer a trust solely in the interest of the beneficiaries without permitting the intrusion of interests of the trustee or third parties that may in any way conflict with the interests of the trust." (Article III, Sec. 3)

"A trust institution has the same right as any other business enterprise to advertise its trust services in appropriate ways. Its advertisements should be dignified and not overstate or overemphasize the qualifications of the trust institutions. There should be no implication that legal services will be rendered." (Article VI, Sec. I)

"Attorneys-at-law constitute a professional group that perform essential functions in relation to trust business and have a community of interest with trust institutions in the common end of service to the public. The maintenance of harmonious relations between trust institutions and members of the Bar is in the best interest of both and of the public as well. It is a fundamental principle of this relationship that trust institutions should not engage in the practice of law." (Article VII, Sec. 2)

These principles thus publicly accepted by the fiduciaries recognized clearly that they may not render legal services to prospective testators or trustors and the necessity of undivided allegiance at all times. While the Bankers' Code does not in terms state that the prospective testator must receive the advice of his own counsel free of divided allegiance, any contrary view would be clearly inconsistent with the principle which it does state that it is the duty of a trustee to administer a trust solely in the interest of the beneficiaries without permitting the interests of the trustee in any way to conflict.

No less important rules are applicable to members of the bar. First of all, there can be no doubt that except for the participation of members of the bar representing

\footnotetext{
${ }^{3}$ Many of these are collected in Hicks and Katz, Unauthorized Practice of Law (I934), Pt. III, pp. 122-171.
} 
fiduciaries in the preparation of wills and trusts, no serious controversy between the fiduciaries and the lawyers could have arisen.

Then, again, the question of whether or not a divided allegiance exists in violation of the canons of ethics governing the lawyer's conduct is primarily a question for the lawyer's conscience, the answer to which may be properly accepted in mostnot all-cases by the fiduciary. Finally, as the New Jersey statement of principles puts it:

"An attorney, consulted or employed by a client with respect to the appointment of a Corporate Fiduciary, selected by the client, in any fiduciary capacity, shall not directly or indirectly influence the client against appointing or having appointed the specified Corporate Fiduciary unless the attorney, in good faith, believes that such Corporate Fiduciary should not be appointed."

The general situation today is in accord with these principles. If it is not altogether perfect, it is to be remembered that perfection is not attainable in any endeavor, and there can be no doubt of the existence of the right spirit between the two organizations, and that being so, it will solve the problems that will arise from time to time in the future. The truth of this is well illustrated by an excerpt from the 1937 report of the Committee on Relations with the Bar of the Trust Division of the American Bankers' Association. Mr. H. O. Edmonds, Chairman of that Committee, said:

"At the annual meeting of the American Bar Association at Boston last August a resolution was offered asserting that state legislation should be enacted making it unlawful for any corporation to advertise that it will act as executor, trustee, guardian, etc. because in so doing it will inevitably be 'practicing law.' This resolution was in due course referred to the Committee on Unauthorized Practice. It was reported unfavorably by that Committee to the House of Delegates of the American Bar Association on January 6th, r937 and was unanimously rejected by the Delegates.

"It is the belief of the Chairman of the Committee that a well selected committee on this subject should at all times be ready and able to function, but that in the normal course of things and unless some controversy arises having general importance, the Committee need not be actively engaged.

"In both the Bar and Trust organizations a steadily increasing disposition was noted to respect each other's rights and to recognize the outstanding and all important fact, which is, that the law is a profession and trusteeship is a business, and that neither one should arrogate to itself the professional status or business status of the other."

As Mr. Edmonds states, the importance of a correct relationship between the fiduciaries and the bar rests on basic principles. These are also recognized in the declaration of the Bankers' Code that attorneys-at-law constitute a professional group that perform essential functions in relation to trust business and have a community of interest with trust institutions in the common end of service to the public. The unlawful practice of the law was selected several years ago as one of five subjects to constitute the National Bar Program of the American Bar Association to coordinate

'Id. at 348 . 
the efforts of bar associations throughout the country in an effort to improve the administration of justice. This selection was made because it had importance far beyond keeping peace between the lawyers and the bankers and beyond preventing title companies, collection agencies, automobile clubs, credit bureaus and innumerable other agencies of one sort or another from furnishing legal services.

Laymen and, indeed, certain lawyers, are apt to view the work of a committee on the unauthorized practice of the law as one of self-preservation for the benefit of the bar alone, but this view is completely wrong and without logical support. As a matter of fact, legal services rendered by or under the direction of laymen are more likely than not to create work for lawyers.

It would be easy enough to describe the evils attending unlawful activities on the part of laymen and corporations in practically every branch of the law, but for purposes of illustration let us consider only some of the questions presented in drawing a will and upon which the lawyer must advise his client.

(I) Should there be a corporate executor or trustees at all? Many instances occur where the fees payable to a corporate fiduciary could to better advantage remain in the testator's family.

(2) Is the particular corporation a satisfactory appointee for the particular estate or trust? The prospective fiduciary's attorney can give but one answer to this question and hold his job.

(3) Should there be a trust at all? A trust is not always desirable. Yet the more trusts, the longer the trusts and the larger the trusts, the more is the money earned by the trustee in fees. Would it not be difficult for the prospective trustee's attorney to advise fewer trusts, shorter trusts and smaller trusts?

(4) What should be the powers and responsibilities of the trustees? In Matter of Knower 5 the will provided: "I direct that such trustee be not confined in making investments to such securities as are authorized by law for the investment of trust funds, but that he shall be at liberty to invest in such stocks, bonds or other securities as he may deem proper, and that he shall not be liable for any loss unless occasioned by his actual fraud." The trustee invested in non-legal securities and resultant losses reduced the trust to almost half of the original corpus. The Court found that the trustee had been improvident and negligent but had not been guilty of actual fraud, and that except for the terms of the will he would have been chargeable with a material part of the losses sustained. The opinion by Surrogate Foley stated: "The responsibility for the lamentable condition of this trust estate rests primarily upon the testator or the draftsman of his will." We may fairly then ask of the attorney for a prospective corporate fiduciary undertaking to draw a will whether he will so draft the clause defining the powers and responsibilities of the trustee as to protect the beneficiaries of the trust or his employer the fiduciary? It is seldom that the testator can be charged with responsibility for the language of a will, for the preparation of a will or trust agreement ordinarily is, as Judge Pound has said, "one of the most difficult tasks that a . . lawyer is called on to perform." Clearly the true protection of a prospective testator or trustor is independent and unbiased advice from an attorney free of any embarrassment by reason of his relations to the prospective corporate fiduciary. ${ }^{6}$

I 122 Misc. 208, 200 N. Y. Supp. 777 (1923).

${ }^{\circ}$ See Opinion 10, Am. Bar Ass'n, Opinions of Committee of Professional Ethics and Grievances (1936) $6 \mathrm{r}$. 
The necessity for maintaining these principles may be made more apparent by calling attention to a case notable for their non-observance. In Jothann v. Irving Trust Company, the plaintiff, an unmarried woman with little business experience, was the owner of shares of stock in a Detroit bank having a value of about $\$ 200,000$. She called upon a representative of the trust company whose duty it was to arrange for the creation of trusts and first discussed with the trust officer the making of a will. He asked her if she knew any lawyers in New York. On being informed that she did not, the trust officer recommended a firm, to whom he transmitted the plaintiff's wishes and instructions and who prepared her will for her. She never met these attorneys or any one from their office and never communicated with them directly. The will itself was executed in the office of the bank. In the preparation and execution of the will she relied entirely on the trust officer. After the will was drawn she again conferred with the trust officer in connection with the creation of an irrevocable trust. It appeared that she appreciated the dangers of speculation and wished to protect her prospective husband and certain close relatives, and for this purpose the holdings of the trust were to be diversified and the bank stocks which constituted her then fortune were to be sold to avoid the possibility of a double liability assessment. The trust officer represented to her that the stock which she then owned was not a suitable investment to be held in the trust and he submitted a list of investments which he thought could be purchased. She was told that if she deposited her Detroit bank stock with the defendant trust company it would sell the stock and reinvest the proceeds in diversified securities and mortgages of high grade and no investments were to be made in bank or in common stock. These details having been agreed upon, the trust officer undertook to have the trust agreement prepared. This was done by the same firm of attorneys who had previously prepared the plaintiff's will. Again she did not meet the attorneys and had no personal communication with them.

The court held that the instrument she signed was not in accord with the understanding she had arrived at with the trust officer; that she had agreed, and thought the instrument she signed so recited, that her bank stock was to be sold and the proceeds reinvested in diversified securities of the kind indicated; that the trust agreement, instead, permitted the trustee in its discretion to hold the entire bank stock as a trust investment and materially restricted the liability of the trustee in the event of loss; that this was not what the plaintiff had bargained for, and the defendant knew it and these provisions could not be availed of as a defense. In directing that the agreement be reformed and an accounting had the court said: 8

"To entitle the plaintiff to relief on this branch of the case it is not necessary to show that the conduct of the defendant was tainted by any evil design or that it involved moral obloquy. This is not a case where the parties dealt at arms' length. We have here a relationship of trust and confidence between the parties, a fiduciary relationship which with all its consequences was called into being not for the first time upon the execution

\footnotetext{
${ }^{7}$ I5I Misc. 107, 270 N. Y. Supp. 721 (1934).

${ }^{8} I d$. at II0, 270 N. Y. Supp. at 725 .
} 
of the agreement, but in the course of the negotiations leading to its preparation. In such a case the courts will grant relief where there is what has been graphically, if not accurately, termed 'constructive' fraud. A court of equity in effect says to a fiduciary: 'It is true that you have had no evil intention to do a wrongful act, but the consequences of your conduct would be so unfair, so unconscionable, that we will not permit you to take advantage of the dependence, the weakness of the one who relied upon you and who trusted you to protect and safeguard her interests. . . .

“... Notwithstanding the forms which were followed, it must in all candor be said that the plaintiff actually received no independent legal advice in connection with the preparation or execution of the trust agreement in controversy. She did not have the benefit of independent counsel, devoted solely to her interests, in explaining the significance and the legal and practical effects of the instrument she signed. She was entitled to actual rather than absentee counsel and advice. Holden, an employee of the defendant, was in effect acting in a dual capacity, attempting to serve two principals with conflicting interests."

If lay control of lawyers were to be allowed, there can be no doubt that the practice of the law as an independent profession would come to an end, for members of the bar observing the standards of conduct required of them by tradition and by the canons of ethics can not compete with solicitation, salesmanship and advertising of lay agencies. The inevitable development would be a group of specialists in lay employ. The collection agencies would hire lawyers to collect accounts and engage in commercial practice, corporate fiduciaries would hire lawyers to prepare wills and trust agreements and advise in the administration of estates, title companies would have a staff of lawyers to do conveyancing business and examine titles, adjusters would employ lawyers to specialize in the field of negligence law, credit associations would direct the activities of their lawyers in matters relating to insolvency. The New York Court of Appeals in Matter of Cooperative Law Company, ${ }^{9}$ at least closed the indirect approach to such conditions. In that case a number of lawyers organized a corporation for the sole purpose of providing legal services of various kinds and through the means of the corporation procuring subscribers or clients. Although this occurred before an amendment to the New York Penal Law had made it a crime for corporations to practice law, the Court of Appeals held that it was fundamental in the law and in the administration of justice that corporations could not engage in the practice of law. In other words, that the character and special training required of lawyers can not be incorporated.

If the bar comes under lay control, then obviously lawyers must look forward to a complete change of status, and the question to be decided is whether or not such a change of status is in the interests of the public. At the present time and for generations past the privilege-not the right-to practice law has rested upon an expression of public policy by statute and by rule. It has been deemed necessary to the proper administration of justice that those seeking admission to the bar should be men of special training, of proven character and high standards of conduct. This is

${ }^{\circ}$ I98 N. Y. 479,92 N. E. 15 (19ro). 
because the administration of justice is in the last analysis that part of the structure of government which is responsible for the maintenance of law and order, the preservation of property rights and personal security. If these standards, established as necessary by the state and accepted and approved by the bar, are requisite in our social order, then certainly laymen should not be allowed to break them down and statutes and rules establishing educational qualifications and ethical standards should be enforced.

As presently constituted the bar, in return for the special franchise granted it and for the special honor of being entrusted with the administration of justice, has undertaken many obligations of duty and service which class it as something other than a business enterprise, such as the duty to defend the poor when assigned for that purpose, to maintain the confidence and preserve inviolate the secrets of a client, to subordinate all personal consideration and at all times to be faithful to the trust imposed. As Mr. Justice Cardozo has said:

"Membership in the bar is a privilege burdened with conditions'-The appellant was received into that ancient fellowship for something more than private gain. He became an officer of the Court, and, like the Court itself, an instrument or agency to advance the ends of justice. His cooperation with the Court was due whenever justice would be imperilled if cooperation was withheld. He might be assigned as counsel for the needy, in causes criminal or civil, serving without pay. He might be directed by summary order to make restitution to a client of moneys or other property wrongfully withheld. He might be censured, suspended, or disbarred for 'any conduct prejudicial to the administration of Justice." "10

It is possible to conceive that this service and these duties can be properly rendered to the public by a lawyer in corporate employ or dependent upon a lay agency for the procurement of business? Obviously not. Mr. Root said in the course of an address to a body of students: "Admission to the Bar is not a mere license to carry on a trade but ... it is an entrance into a profession with honorable traditions of service." No high sense of service to the public and no proper realization of duty to be performed can possibly exist on the part of a lawyer whose daily living depends upon satisfying, not the client to whom he owes his service, but the employer who gives him his pay check at the end of the month. Financial success is, of course, desirable, but the measure of true success comprehends something more than the results obtained for a particular client-for the results obtained and the methods employed in obtaining the results must not conflict with the obligations and ideals of the profession growing out of the requirements essential to a true administration of justice in the interests of all.

It is a necessary corollary of this that the bar faithfully discharge its responsibilities to the public. In Igro, Woodrow Wilson made the annual address to the American Bar Association. It was entitled: "The Lawyer and the Community." The address was a plea for individual independence and the maintenance by the profession of

\footnotetext{
${ }^{30}$ Pcople ex rel. Karlin v. Cullin, 248 N. Y. 465,470 , I6z N. E. 487,489 (Ig28).
} 
the ideal of service not only to clients but even more to the state itself. He said, in part, to the members of the American Bar Association:

"You are not a mere body of expert business advisers in the field of civil law or a mere body of expert advocates for those who get entangled in the meshes of the criminal law. You are servants of the public, of the state itself. You are under bonds to serve the general interest, the integrity and enlightenment of law itself, in the advice you give individuals. It is your duty also to advise those who make the laws-to advise them in the general interest, with a view to the amelioration of every undesirable condition that the law can reach, the removal of every obstacle to progress and fair dealing that the law can remove, the lightening of every burden the law can lift and the righting of every wrong the law can rectify. The services of the lawyer are indispensable not only in the application of the accepted processes of the law, the interpretation of existing rules in the daily operations of life and business. His services are indispensable also in keeping, and in making, the law clear with regard to responsibility, to organization, to liability, and, above all, to the relation of private rights to the public interest."

In conclusion then it may be said that the existence of satisfactorily operating declarations of principles acceptable to the fiduciaries and the bar associations and the steady decrease in litigation between the two indicate not only a cordial relationship but also that the relationship rests on the sound foundation of recognition by each of their respective rights and of their duties to the public. 